\title{
PENGUJIAN DAYA PANCAR ANTENA YAGI TERHADAP EMPAT JENIS ANTENA PENERIMA
}

\author{
Andi Sri Irtawaty ${ }^{1}$, Maria Ulfah $^{2}$, Hadiyanto $^{3}$ \\ 1,2,3 Jurusan Teknik Elektronika Politeknik Negeri Balikpapan \\ E-mail: andi.sri@poltekba.ac.id, maria.ulfah@poltekba.ac.id, hadiyanto@poltekba.ac.id
}

\begin{abstract}
In this study, yagi antena is used as a receiving antena at a frequency of $500 \mathrm{MHz}$. The receiving antena to be tested for its characteristics are 4 types, namely dipole antena, monopole antena, circular loop antena and yagi antena. The purpose of this research is to know the quality of antena yagi as the sending antena to 4 types of receiving antena tested. The parameters used as benchmark comparison is the gain and antena polarization.

The process of measuring the parameters of antena yagi as transmitter antena and dipole antena, monopole antena, circular loop antena and yagi antena as the receiving antena is done by an antena trainner with supporting software. Data retrieval is done in 2 conditions namely Line Of Sight (LOS) and using obstacle (NO-LOSS). The distance between the transmitting antena and the receiving antena is 1.5 meters, 2 meters, 2.5 meters, 3 meters and 5 meters. The slope position of the antena is also a determining factor in the measurement process. There are 3 categories namely, horizontal (antena sender) and horizontal (antena receiver), vertikal (antena sender) and vertikal (antena receiver) and combination of horizontal (antena sender) and vertikal (antena receiver)..

The results of antena quality testing showed that among the 4 types of antena (dipole, monopole, circular loop and yagi), it was proven that the yagi antena had a perfect $100 \%$ accuracy test. The yagi antena is proved to have a gain value and an ideal radiation pattern, so it is suitable to be implemented as a transmitting antena and receiving antena.
\end{abstract}

Keywords: gain, LOS, NLOS, yagi, polarization antena

\section{INTISARI}

Pada penelitian ini, digunakan antena yagi sebagai antena penerima pada frekuensi $500 \mathrm{MHz}$. Antena penerima yang akan diuji karakteristiknya ada 4 jenis, yaitu antena dipole, antena monopole, antena circular loop dan antena yagi. Tujuan penelitian ini adalah untuk mengetahui kualitas antena yagi sebagai antena pengirim terhadap 4 jenis antena penerima yang diujikan. Adapun parameter yang digunakan sebagai tolok ukur pembandingnya adalah gain dan polarisasi antena. Proses pengukuran parameter-parameter antena yagi sebagai antena pemancar dan antena dipole, antena monopole, antena circular loop dan antena yagi sebagai antena penerima dilakukan dengan sebuah alat/ trainner antena yang dilengkapi software pendukung. Pengambilan data dilakukan pada 2 kondisi yaitu secara Line Of Sight (LOS) dan menggunakan obstacle (NO-LOSS). Jarak antara antena pemancar dan antena penerima yaitu 1.5 meter, 2 meter, 2.5 meter, 3 meter dan 5 meter. Posisi kemiringan antena juga menjadi faktor penentu dalam proses pengukuran. Ada 3 kategori yaitu, horizontal (antena pengirim) dan horizontal (antena penerima), vertikal (antena pengirim) dan vertikal (antena penerima) serta kombinasi horizontal (antena pengirim) dan vertikal (antena penerima).

Hasil pengujian kualitas antena menunjukkan bahwa di antara 4 jenis antena (dipole, monopole, circular loop dan yagi), terbukti bahwa antena yagi memiliki tingkat akurasi pengujian yang sangat sempurna sebesar $100 \%$. Antena yagi terbukti memiliki nilai gain dan pola radiasi yang sangat ideal, sehingga sangat cocok diimplementasikan sebagai antena pemancar dan antena penerima

Kata Kunci : gain, LOS, NLOS, polarisasi antena, yagi

\section{PENDAHULUAN}

Antena (antena atau areal) adalah perangkat yang berfungsi untuk memindahkan energi gelombang elektromagnetik dari media kabel ke udara atau sebaliknya dari udara ke media kabel. Karena merupakan perangkat perantara antara media kabel dan udara, maka antena harus mempunyai sifat yang sesuai (match) dengan media kabel pencatunya. Prinsip ini telah diterangkan dalam saluran transmisi.

Untuk mengetahui kualitas suatu antena, beberapa parameter ukur harus diujikan yaitu:

1. gain,

2. pola radiasi,

3. lebar band (bandwidth),

4. besar sudut berkas pancaran gelombang (beamwidth), 
5. impedansi input yang dimiliki,

6. directivitas.

Berdasarkan fungsinya antena dibedakan dalam 2 macam yaitu: antena pemancar dan antena penerima. Sifat antena ada dua yaitu omnidirectional dan directional.

Pada penelitian ini, akan dilakukan pengujian kualitas antena yagi sebagai antena pengirim terhadap empat jenis antena penerima yaitu antena dipole, antena monopole, antena circular dipole dan antena yagi, secara bergantian. Parameter uji yang digunakan ada 2, yaitu gain dan pola radiasi. Pengujian ini dilakukan dengan beberapa kondisi, yaitu :

1. Kondisi Line of Sight (LOS) dan kondisi dengan menggunakan obstacle (NO-LOSS).

2. Posisi kemiringan antena yaitu E-Plane (horizontal-horizontal), H-Plane (vertikalvertikal) dan kombinasi E-Plane dan $H$ Plane.

3. Jarak pengujian antena pemancar dan antena penerima adalah 1,5 meter, 2 meter, 2.5 meter, 3 meter dan 5 meter untuk frekuensi $500 \mathrm{MHz}$.

\section{DASAR TEORI}

Dalam sejarah komunikasi, perkembangan teknik informasi tanpa menggunakan kabel ditetapkan dengan nama "Antena". Antena berasal dari bahasa latin "Antena" yang berarti "tiang kapal layar". Dalam pengertian sederhana kata latin ini berarti juga "penyentuh atau peraba" sehingga kalau dihubungkan dengan teknik komunikasi berarti bahwa antena mempunyai tugas menyelusuri jejak gelombang elektromagnetik, hal ini jika antena berfungsi sebagai penerima. Sedangkan jika sebagai pemancar maka tugas antena tersebut adalah menghasilkan sinyal gelombang elektromagnetik.

Sinyal gelombang radiasi elektromagnetik yang berasal dari antena terdiri dari dua komponen yaitu medan listrik dan medan magnetik. Antena pemancar dibagi menjadi dua klasifikasi dasar yaitu: Antena Hertz (half-wave) dan Antena Marconi (quarter-wave). Antena Hertz biasanya dipasang sepanjang dengan ground dan diposisikan untuk memancarkan gelombang vertikal ataupun horizontal. Antena marconi dioperasikan dengan sebuah akhir yang ditanahkan dan disambung secara tegak lurus menuju tanah atau permukaan yang berfungsi sebagai ground.

Adapun simbol antena disajikan pada Gambar 1.

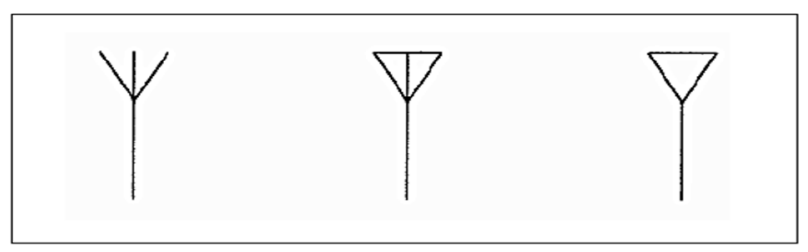

Gambar 1. Simbol antena [3]

Sifat antena ada dua yaitu omnidirectional dan directional. Antena directional,yaitu antena yang mempunyai pola pemancaran sinyal dengan satu arah tertentu. Antena ini idealnya digunakan sebagai penghubung antar gedung atau untuk daerah (konfigurasi Point to Point) yang mempunyai konfigurasi cakupan area yang kecil seperti pada lorong-lorong yang panjang.

Antena jenis directional merupakan jenis antena dengan narrow beamwidth, yaitu punya sudut pemancaran yang kecil dengan daya lebih terarah, jaraknya jauh dan tidak bisa menjangkau area yang luas, antena directional mengirim dan menerima sinyal radio hanya pada satu arah, umumnya pada fokus yang sangat sempit, dan biasanya digunakan untuk koneksi point to point, atau multiple point, contoh antena directional seperti antena grid, dish "parabolic", yagi, dan antena sectoral. Yang termasuk antena directional adalah antena model yagi seperti kebanyakan yang dipakai sebagai antena penerima siaran TV. Atennayagi, dengan logperiodik antena, dan sudut reflektor, yang sering digabungkan dan dijual sebagai hunian komersial antena TV.

Antena Omnidirectional dapat memancarkan gelombang ke segala arah. Salah satu antena jenis omnidirectional adalah antena monopole. Pola radiasinya adalah ke segala arah.

Semua antena secara umum baik bentuk dan ukurannya mempunyai empat karakteristik dasar yaitu directivity, gain, polarization dan beamwidth. 


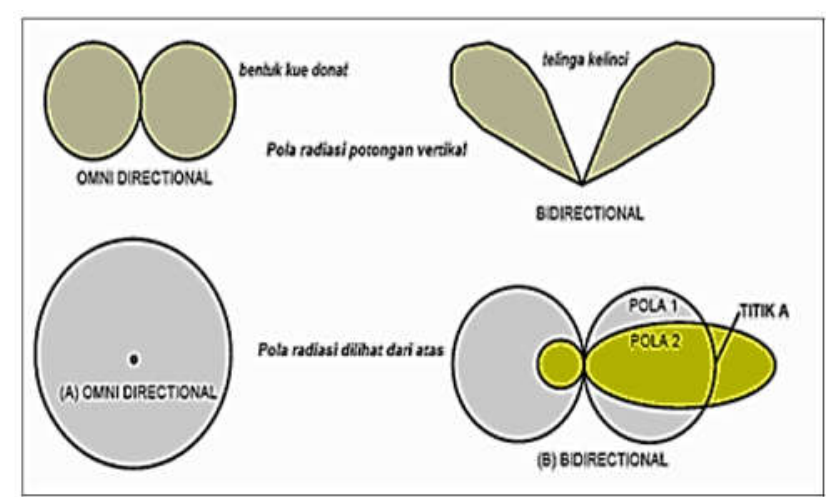

Gambar 2. Pola radiasi antena [3]

Selain pola radiasi, parameter penting yang akan diujikan dalam penelitian ini adalah gain antena. Gain antena adalah karakter antena yang terkait dengan kemampuan antena mengarahkan radiasi sinyalnya, atau penerimaan sinyal dari arah tertentu. Satuannya adalah $\mathrm{dB}, \mathrm{dBm}$ atau $\mathrm{dBi}$.

\section{METODE PENELITIAN}

\section{A. Variabel Penelitian}

Berdasarkan pokok permasalahan yang dirumuskan maka variabel (parameter) yang di analisis dalam penelitian ini adalah sebagai berikut:

1. Gain antena

2. Pola radiasi antena

Dengan menggunakan antena trainner akan diperoleh hasil pengukuran dua parameter tersebut. Antena yang digunakan sebagai pengirim adalah antena yagi, sedangkan antena penerima yang diujikan adalah antena dipole, antena monopole, antena circular loop dan antena yagi, yang diukur secara bergantian.

\section{B. Rancangan Penelitian}

Rancangan penelitian merupakan keseluruhan proses penelitian dari awal hingga tahap akhir, dan disajikan dalam bentuk flowchart.

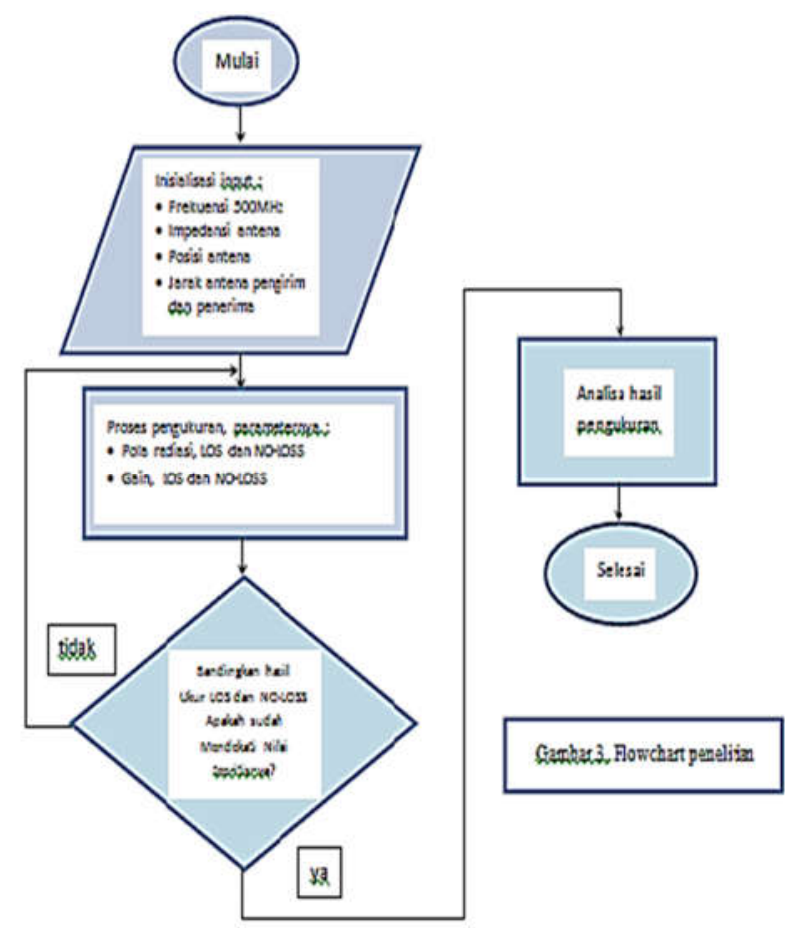

Gambar 3. Flowchart langkah penelitian

\section{HASIL DAN PEMBAHASAN}

\section{A. Analisa Hasil}

Dalam menganalisa hasil pengukuran gain dan pola radiasi dalam penelitian ini dilakukan dengan beberapa kondisi:

1. Kondisi antena pemancar dan antena penerima bersifat LOSS dan NO-LOSS.

2. Posisi kemiringan antena pemancar dan antena penerima ada 3 , yaitu :
a. Horizontal-horizontal (E-Plane)
b. Vertikal-vertikal (H-Plane)
c. Horizontal-vertikal (kombinasi $E$ - Plane dan H-Plane)

3. Jarak antara antena pemancar dan antena penerima ada 5 variasi, yaitu :
a. 1.5 meter
b. 2 meter
c. 2.5 meter
d. 3 meter
e. 5 meter

\section{B. Pengukuran Gain dan Pola Radiasi}

Pengukuran gain dan pola radiasi antena dilakukan mulai dari azimuth $0^{0}$ sampai $330^{\circ}$. Hasil pengukuran selengkapnya akan disajikan secara step by step untuk keempat antena penerima (antena dipole, antena monopole, antena circular loop dan antena yagi. 
1. Pengukuran Gain dan Pola Radiasi Antena Dipole pada Kondisi Loss

Tabel 1 berikut ini menyajikan sampel pola radiasi antena dipole pada kondisi LOSS dan posisi antena dipole horizontal (E-Plane), dengan sudut azimuth $0^{0}$ sampai $330^{\circ}$.

Tabel 1. Pengukuran Gain dan Polarisasi Antena Dipole pada Kondisi Loss (E-Plane)
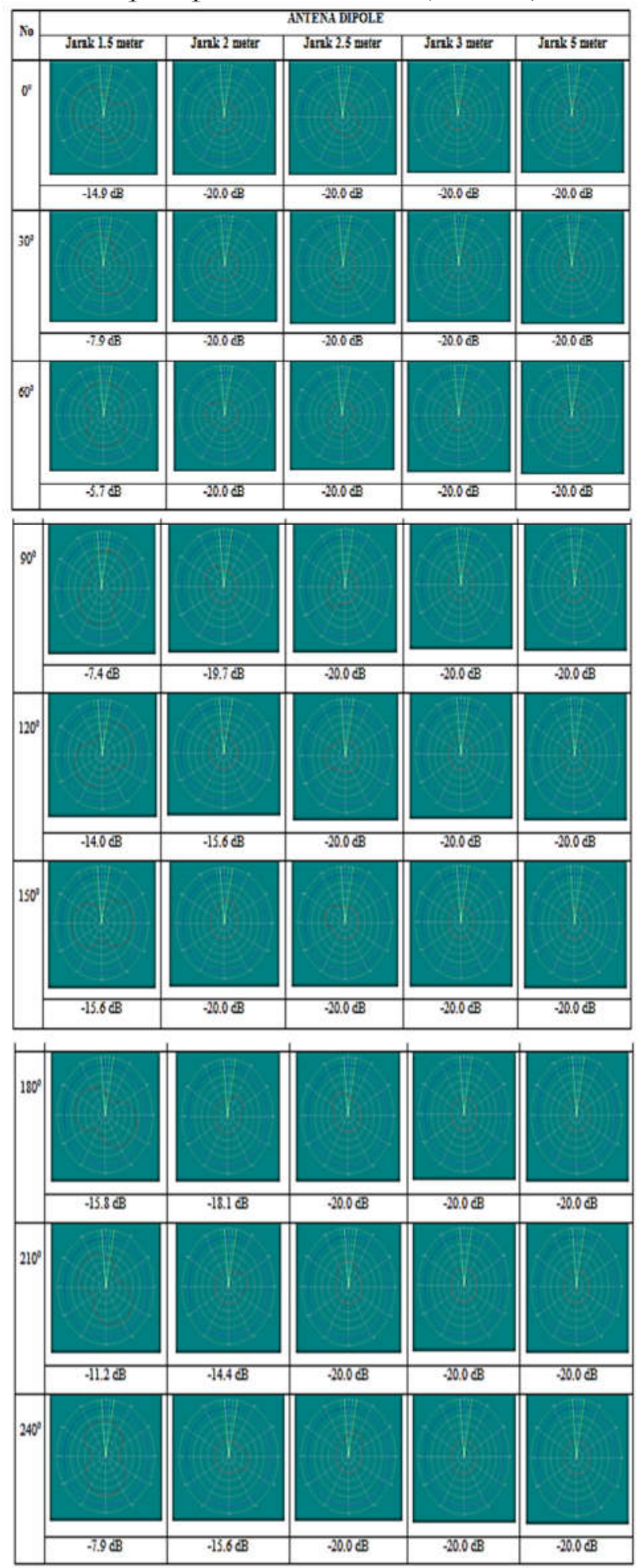

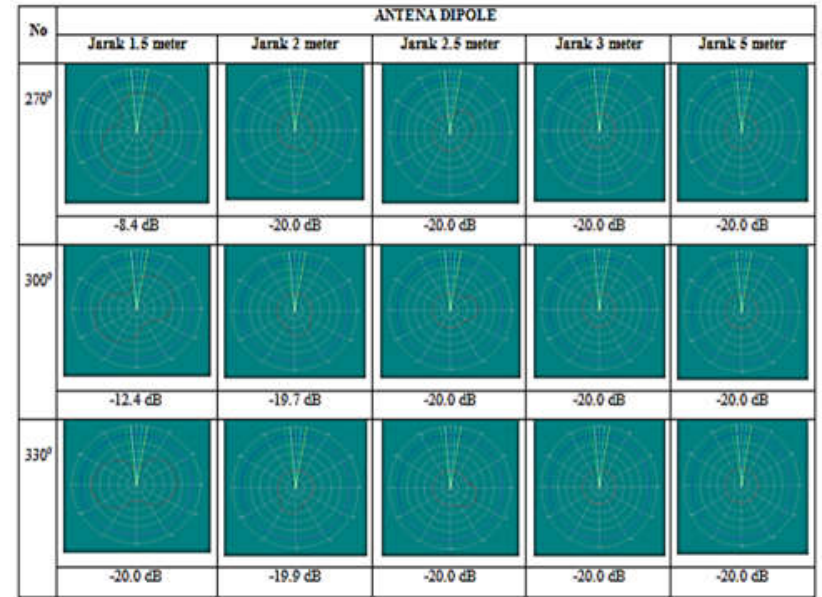

Hasil pengukuran gain rata-rata antena dipole pada kondisi LOSS dan 3 variasi posisi antena dipole yaitu E-Plane, H-Plane dan kombinasi E-Plane H-Plane akan disajikan pada Tabel 2.

Tabel 2. Nilai gain rata-rata antena dipole kondisi Loss

\begin{tabular}{|c|c|c|c|c|}
\hline \multirow{2}{*}{$\begin{array}{l}\text { Jank anteuns } \\
\text { (neter) }\end{array}$} & \multirow{2}{*}{$\begin{array}{c}\text { E-Plase } \\
\text { (Borizontal-borisontal) }\end{array}$} & \multirow{2}{*}{$\begin{array}{c}\text { H-Plane } \\
\text { (rertical-rertikal) }\end{array}$} & \multicolumn{2}{|c|}{$\begin{array}{l}\text { Kombinasi E-Plane den H-Plase } \\
\text { (porizontal - rertical) }\end{array}$} \\
\hline & & & EPlan? & H-Plene \\
\hline 1.5 & $-11.8 \mathrm{~dB}$ & $-9,4 \bar{B}$ & $-13.3 \mathrm{CB}$ & $-13.2 \mathrm{~dB}$ \\
\hline 2 & $-18.6 \mathrm{~dB}$ & $-14.7 \mathrm{CB}$ & $-18.6 \mathrm{~dB}$ & $-19 \mathrm{CB}$ \\
\hline 2.5 & $20 \mathrm{CB}$ & $-18 \mathrm{AB}$ & $-19.9 \mathrm{~dB}$ & $-19.7 \mathrm{BB}$ \\
\hline 3 & $20 \mathrm{CB}$ & $-20 \mathrm{~dB}$ & $20 \mathrm{CB}$ & $.20 \mathrm{BB}$ \\
\hline 5 & $20 \mathrm{BB}$ & $-20 \mathrm{~dB}$ & $-20 \mathrm{~dB}$ & $-20 \mathbb{B}$ \\
\hline Gein ratarata & $-18.1 \mathrm{~dB}$ & $-16.4 \mathrm{~dB}$ & $-18.4 \mathrm{CB}$ & $-18.4 \mathrm{~dB}$ \\
\hline
\end{tabular}

Secara teoritis, semakin bertambah jarak antena, maka nilai gain antena akan semakin berkurang. Ada 20 nilai gain rata-rata antena dipole yang terukur dan disajikan pada Tabel 2. Hasilnya menunjukkan bahwa nilai gain yang terukur selaras dengan pernyataan teoritisnya. Berarti persentase keakuratan hasil pengukuran gain dapat diperoleh dengan rumus berikut :

$$
\begin{aligned}
& \% \text { Keakurata.n }=\frac{j u m l a h \cdot d a t a \cdot t e r u k u r-j u m l a h \cdot d a t a \cdot y g \cdot \text { error }}{j u m l a h \cdot d a t a \cdot t e r u k u r} \times 100 \% \\
& \% \text { Keakurata.n }=\frac{20-0}{20} \times 100 \%=100 \%
\end{aligned}
$$

2. Pengukuran Gain dan Pola Radiasi Antena Dipole pada Kondisi NO-LOSS

Hasil pengukuran gain rata-rata antena dipole pada kondisi NO-LOSS dan 3 variasi posisi antena dipole yaitu E-Plane, H-Plane dan kombinasi E-Plane H-Plane akan disajikan pada Tabel 3. 
Tabel 3. Nilai gain rata-rata antena dipole kondisi No-NO-Loss

\begin{tabular}{|c|c|c|c|c|}
\hline \multirow{2}{*}{$\begin{array}{l}\text { Janak astenna } \\
\text { (meter) }\end{array}$} & \multirow{2}{*}{$\begin{array}{c}\text { E-Plane } \\
\text { (Borizontal-horisontal) }\end{array}$} & \multirow{2}{*}{$\begin{array}{c}\text { H-Plase } \\
\text { (vertical-vertikal) }\end{array}$} & \multicolumn{2}{|c|}{$\begin{array}{l}\text { Kombiassi E-Plane dan H-Plase } \\
\text { (sorizoutal - rertical) }\end{array}$} \\
\hline & & & Eplane & H.Plan? \\
\hline 1.5 & $-12.21 \mathrm{~dB}$ & $-13.4 \mathrm{CB}$ & $-13.84 \mathrm{~dB}$ & $-14.42 \mathrm{~dB}$ \\
\hline 2 & $-19.01 \mathrm{~B}$ & $-15.43 \mathrm{~dB}$ & $-18.72 \mathrm{~dB}$ & $-18.99 \mathrm{~dB}$ \\
\hline 2.5 & $-19.06 \AA B$ & $-14.19 \mathrm{~dB}$ & $-19.22 \mathrm{~dB}$ & $-19.24 \mathrm{~dB}$ \\
\hline 3 & $-20.0 \mathrm{AB}$ & $-20.0 \mathrm{~dB}$ & $-20.0 \mathrm{BB}$ & $20.0 \mathrm{CB}$ \\
\hline 5 & $-20.0 \mathrm{~dB}$ & $-20.0 \mathrm{~dB}$ & $-20.0 \mathrm{CB}$ & $20.0 \mathrm{~dB}$ \\
\hline Gein raturatia & $-18.1 \mathrm{CB}$ & $-16.4 \AA B$ & $-18.4 \mathrm{CB}$ & $-18.5 \mathrm{CB}$ \\
\hline
\end{tabular}

Berdasarkan Tabel 3 terlihat ada 2 data yang error, yaitu pada kondisi H-Plane, yaitu pada jarak 2 meter, nilai gain rata-rata antena dipole $15.43 \mathrm{~dB}$ sedangkan pada jarak 2.5 meter, nilai gain rata-rata antena dipole $-14.19 \mathrm{~dB}$. Berarti prosentase keakuratan hasil pengukuran gain dapat diperoleh dengan rumus berikut:

$\%$ Keakurata.n $=\frac{j u m l a h \cdot d a t a \cdot t e r u k u r-j u m l a h \cdot d a t a \cdot y g \cdot e r r o r}{} \times 100 \%$ jumlah·data·terukur

$\%$ Keakurata.n $=\frac{20-2}{20} \times 100 \%=90 \%$

3. Pengukuran Gain dan Pola radiasi Antena Monopole pada kondisi LOSS

Tabel 4 berikut ini menyajikan sampel pola radiasi antena monopole pada kondisi LOSS dan posisi antena monopole horizontal (E-Plane), dengan sudut azimuth $0^{0}$ sampai $330^{\circ}$.

Tabel 4. Pengukuran gain dan pola radiasi antena monopole pada kondisi Loss (E-Plane)
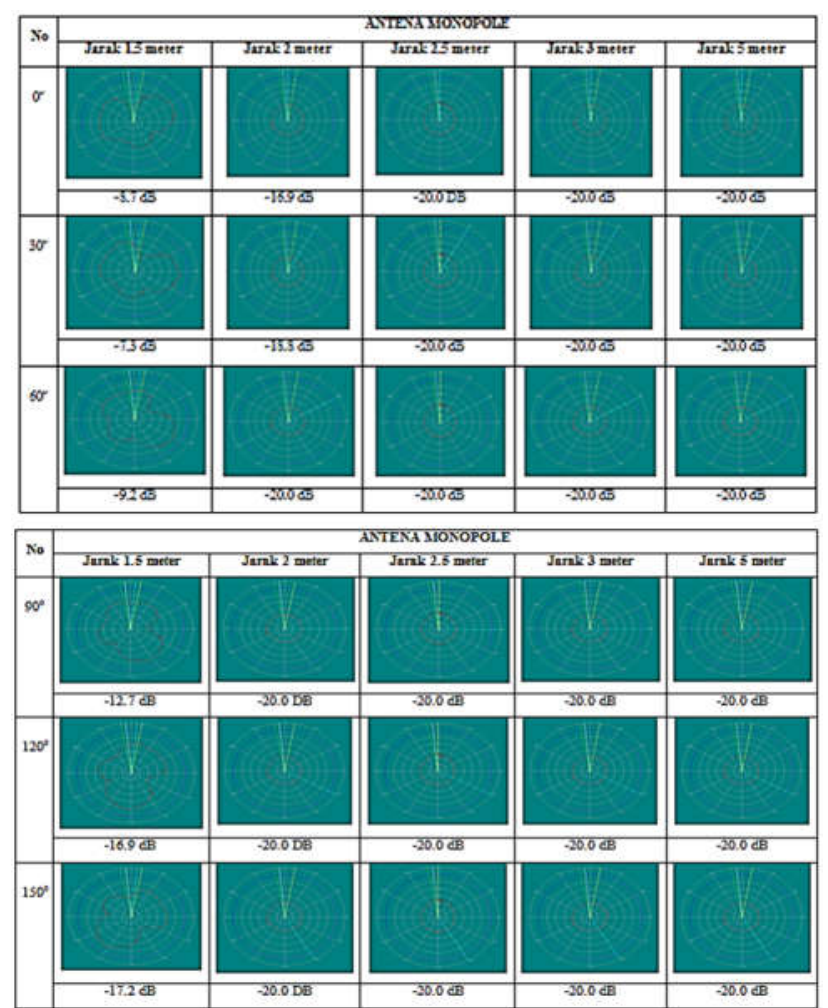
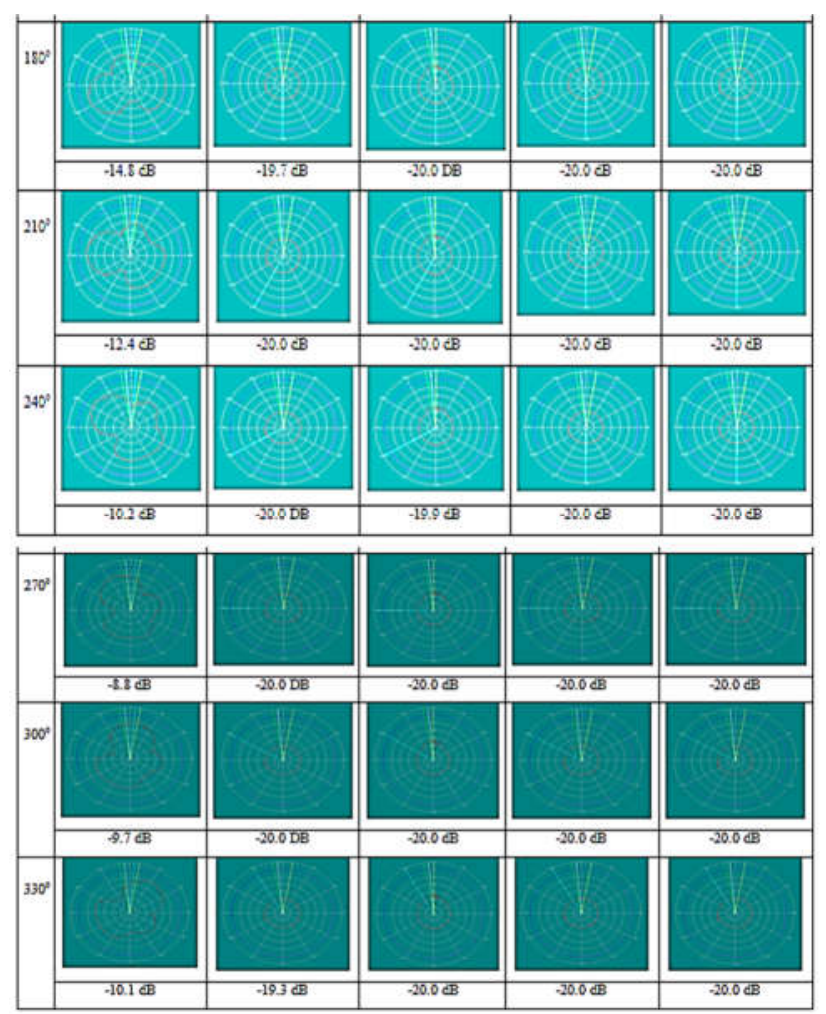

Hasil pengukuran gain rata-rata antena monopole pada kondisi LOSS dan 3 variasi posisi antena monopole yaitu E-Plane, H-Plane dan kombinasi E-Plane H-Plane akan disajikan pada Tabel 5 .

Tabel 5. Nilai gain rata-rata antena monopole kondisi LOSS

\begin{tabular}{|c|c|c|c|c|}
\hline \multirow{2}{*}{$\begin{array}{l}\text { Jarak anteona } \\
\text { (meter) }\end{array}$} & \multirow{2}{*}{$\begin{array}{c}\text { E-Plase } \\
\text { (Borizostal-borisontal) }\end{array}$} & \multirow{2}{*}{$\begin{array}{c}\text { H.Plase } \\
\text { (vertical-rertikal) }\end{array}$} & \multicolumn{2}{|c|}{$\begin{array}{l}\text { Kombinssi E-Plave dan H.Plane } \\
\text { (aorizostal - rertical) }\end{array}$} \\
\hline & & & E-Plane? & H.Plane \\
\hline 1.5 & $-12.4 \mathrm{~dB}$ & $-16.1 \mathrm{~dB}$ & $-14.2 \mathrm{~dB}$ & $-14.6 \mathrm{~dB}$ \\
\hline 2 & $-19.9 \mathrm{~dB}$ & $-17.3 \mathrm{~dB}$ & $-15.8 \mathrm{~dB}$ & $-15.5 \mathrm{~dB}$ \\
\hline 2.5 & $-19.5 \mathrm{CB}$ & $-19.5 \mathrm{~dB}$ & $-19.2 \mathrm{~dB}$ & $-18.5 \mathrm{~dB}$ \\
\hline 3 & $-20.0 \mathrm{~dB}$ & $-20.0 \mathrm{~dB}$ & $-20.0 \mathrm{~dB}$ & $-20.0 \mathrm{~dB}$ \\
\hline 5 & $-20.0 \mathrm{~dB}$ & $-20.0 \mathrm{~dB}$ & $-20.0 \mathrm{~dB}$ & $-20.0 \mathrm{~dB}$ \\
\hline Gein ratarata & $-18.36 \mathrm{~dB}$ & $-18.58 \mathrm{~dB}$ & $-17.84 \mathrm{~dB}$ & $-17.72 \mathrm{~dB}$ \\
\hline
\end{tabular}

Nilai gain antena monopole yang disajikan pada Tabel 5 memperlihatkan pada kondisi pengukuran gain E-Plane, terjadi penyimpangan teori yaitu pada jarak 2 meter, nilai gain rata-rata -19.9 dB dan pada jarak 2.5 meter, nilai gain rata-rata $-19.5 \mathrm{~dB}$. Berarti prosentase keakuratan hasil pengukuran gain rata-rata antena monopole kondisi LOSS dapat diperoleh dengan rumus berikut:

\footnotetext{
$\%$ Keakurata.n $=\frac{\text { jumlah } \cdot \text { data } \cdot \text { terukur }-j u m l a h \cdot d a t a \cdot y g \cdot e r r o r}{j u} \times 100 \%$ jumlah.data·terukur

$\%$ Keakurata.n $=\frac{20-2}{20} \times 100 \%=90 \%$
} 
4. Pengukuran Gain dan Pola radiasi Antena Monopole pada kondisi NO-LOSS

Tabel 6 berikut ini menyajikan sampel pola radiasi antena monopole pada kondisi NO-LOSS dan posisi antena monopole horizontal (E-Plane), dengan sudut azimuth $0^{0}$ sampai $330^{\circ}$.

Tabel 6. Nilai gain rata-rata antena monopole pada kondisi NoLoss

\begin{tabular}{|c|c|c|c|c|}
\hline \multirow{2}{*}{$\begin{array}{l}\text { Jarnk antemsa } \\
\text { (auter) }\end{array}$} & \multirow{2}{*}{$\begin{array}{c}\text { E-Plane } \\
\text { (Borizontal-borisontal) }\end{array}$} & \multirow{2}{*}{$\begin{array}{c}\text { H-Plase } \\
\text { (rertical-rertikal) }\end{array}$} & \multicolumn{2}{|c|}{$\begin{array}{l}\text { Koubinesi E-Plane das H-Plave } \\
\text { (Borizontal - rertical) }\end{array}$} \\
\hline & & & EPles? & H.Plers? \\
\hline 1.5 & $-15.1 \mathrm{CB}$ & $-10.2 \mathrm{~dB}$ & $-15.7 \mathrm{CB}$ & $-16.7 \mathrm{~B}$ \\
\hline 2 & $-16.3 \sqrt{B}$ & $-18.8 \mathrm{CB}$ & $-19.5 \AA \mathrm{B}$ & $-19.4 \mathrm{~dB}$ \\
\hline 2.5 & $-19.7 \mathrm{~B}$ & $-19.3 d \mathrm{~B}$ & $-19.2 \mathbb{B}$ & $-18.5 \bar{B}$ \\
\hline 3 & $-20.0 \Subset B$ & $-20.0 \mathrm{~dB}$ & $.20 .0 \mathrm{~dB}$ & $-20.0 \mathrm{~dB}$ \\
\hline 5 & $-20.0 \mathrm{BB}$ & $-20.0 \mathrm{~B}$ & $-20.0 \mathrm{~dB}$ & $20.0 \mathrm{CB}$ \\
\hline Gin ratsata & $-18.22 \mathrm{CB}$ & $-17.65 \mathrm{~dB}$ & $.18 .88 \mathrm{CB}$ & $-18.92 \mathrm{AB}$ \\
\hline
\end{tabular}

Nilai gain antena monopole yang disajikan pada Tabel 6 memperlihatkan hasil pengukuran gain rata-rata pada kondisi kombinasi E-Plane $H$-Plane, terjadi penyimpangan teori yaitu pada jarak 2 meter, nilai gain rata-rata pada E-Plane -19.5 dB dan pada jarak 2.5 meter, nilai gain rata-rata E-Plane -19.2 dB. Demikian pula untuk H-Plane kombinasi, pada jarak 2 meter, nilai gain rata-rata $-19.4 \mathrm{~dB}$ dan pada jarak 2.5 meter, nilai gain rata-rata $-18.5 \mathrm{~dB}$. Berarti prosentase keakuratan hasil pengukuran gain rata-rata antena monopole kondisi NO-LOSS dapat diperoleh dengan rumus berikut:

$$
\begin{aligned}
& \% \text { Keakurata.n }=\frac{j u m l a h \cdot d a t a \cdot t e r u k u r-j u m l a h \cdot d a t a \cdot y g \cdot \text { error }}{j u m l a h \cdot d a t a \cdot t e r u k u r} \times 100 \% \\
& \% \text { Keakurata.n }=\frac{20-4}{20} \times 100 \%=80 \%
\end{aligned}
$$

5. Nilai gain rata-rata Antena Circular loop pada kondisi LOSS

Tabel 7 berikut ini menyajikan sampel pola radiasi antena circular loop pada kondisi LOSS dan posisi antena circular loop horizontal ( $E$ Plane), dengan sudut azimuth $0^{0}$ sampai $330^{\circ}$.
Tabel 7. Pengukuran gain dan pola radiasi antena circular loop pada kondisi Loss (E-Plane)
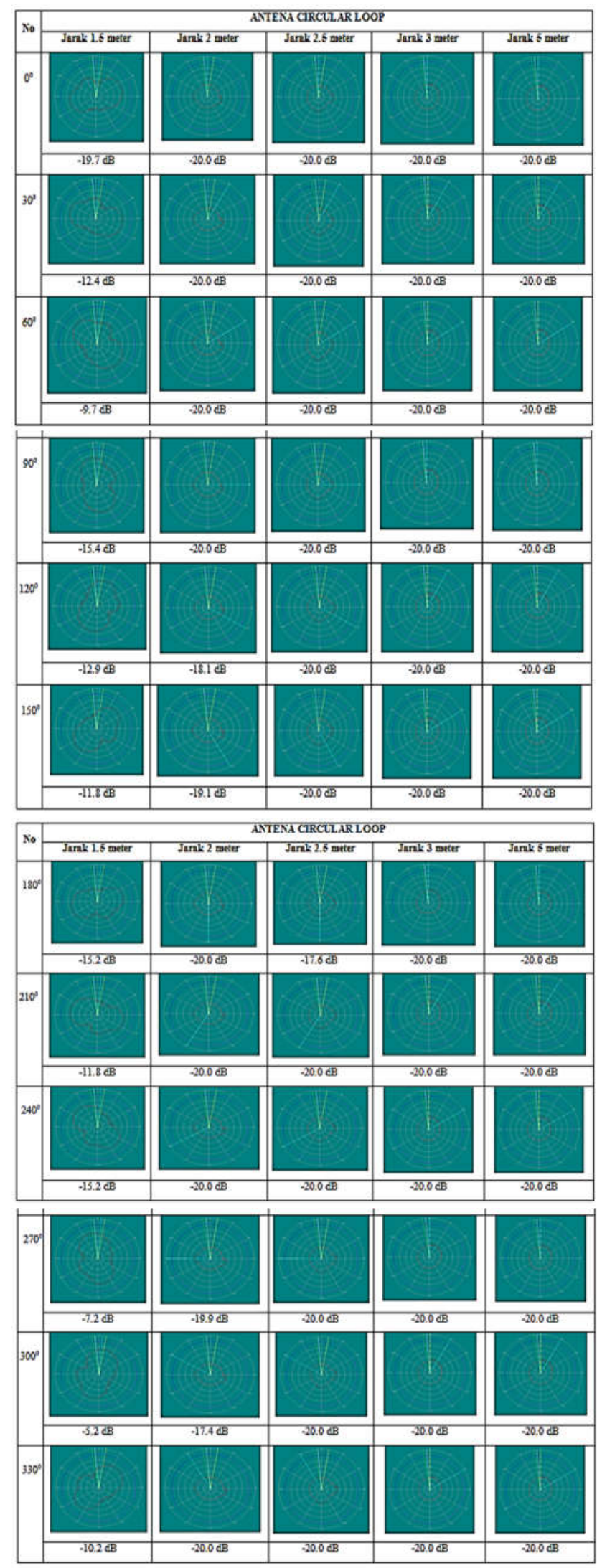
Tabel 8 Nilai gain rata-rata antena circular loop pada kondisi No-Loss

\begin{tabular}{|c|c|c|c|c|}
\hline \multirow{2}{*}{$\begin{array}{l}\text { Jank antense } \\
\text { (ater) }\end{array}$} & \multirow{2}{*}{$\begin{array}{c}\text { E-Plase } \\
\text { (Porizostal-borisostal) }\end{array}$} & \multirow{2}{*}{$\begin{array}{c}\text { H.Plase } \\
\text { (rertical-rertikal) }\end{array}$} & \multicolumn{2}{|c|}{$\begin{array}{l}\text { Konabinsi E-Plane dan H-Plase } \\
\text { (porizontal - rertical) }\end{array}$} \\
\hline & & & EPlang & H.Plan: \\
\hline 1.5 & $9.0 \mathrm{~dB}$ & $-14.3 \mathrm{BB}$ & $-15.4 \mathbb{B}$ & $-15.3 \mathrm{~B}$ \\
\hline 2 & $-18.4 \mathrm{CB}$ & $.19 \bar{B}$ & $-19.1 \bar{B}$ & $-19.1 \mathbb{B}$ \\
\hline 2.5 & $.19 .8 \mathrm{~B}$ & $-18.2 \mathrm{~dB}$ & $-18.31 \mathrm{CB}$ & $-19.7 \mathrm{~B}$ \\
\hline 3 & $20.0 \mathrm{~B}$ & $.20 .0 \mathrm{~dB}$ & $20.0 \mathrm{CB}$ & $20.0 \mathrm{CB}$ \\
\hline 5 & $20.0 \mathrm{~dB}$ & $.20 .0 \bar{B}$ & $20.0 \mathrm{~dB}$ & $20.0 \mathrm{~dB}$ \\
\hline Cón etata & $-17.44 \mathrm{BB}$ & $-18.3 \mathrm{CB}$ & $.18 .56 \mathrm{CB}$ & $.18 .82 \mathrm{BB}$ \\
\hline
\end{tabular}

Nilai gain antena circular loop yang disajikan pada Tabel 8 memperlihatkan ada 4 data hasil pengukuran gain rata-rata yang menyimpang dari pernyataan teori. Pertama yaitu pada kondisi kombinasi E-Plane H-Plane, pada jarak 2 meter, nilai gain rata-rata pada-19.1 $\mathrm{dB}$ dan pada jarak 2.5 meter, nilai gain rata-rata -18.31 dB. Kedua yaitu pada kondisi H-Plane, pada jarak 2 meter, nilai gain rata-rata pada -19 $\mathrm{dB}$ dan pada jarak 2.5 meter, nilai gain rata-rata $-18.2 \mathrm{~dB}$. Berarti prosentase keakuratan hasil pengukuran gain rata-rata antena circular loop kondisi NO-LOSS dapat diperoleh dengan rumus berikut :

$\%$ Keakurata.n $=\frac{j u m l a h \cdot d a t a \cdot t e r u k u r-j u m l a h \cdot d a t a \cdot y g \cdot \text { error }}{j u m l a h \cdot d a t a \cdot t e r u k u r} \times 100 \%$

$\%$ Keakurata. $n=\frac{20-4}{20} \times 100 \%=80 \%$

6. Nilai gain rata-rata Antena Circular loop pada kondisi NO-LOSS

Tabel 9 berikut ini menyajikan sampel pola radiasi antena circular loop pada kondisi NOLOSS dan posisi antena monopole horizontal ( $E$ Plane), dengan sudut azimuth $0^{0}$ sampai $330^{\circ}$.

Tabel 9. Nilai gain rata-rata antena circular loop pada kondisi NoLoss

\begin{tabular}{|c|c|c|c|c|}
\hline \multirow{2}{*}{$\begin{array}{l}\text { Jank anteana } \\
\text { (meter) }\end{array}$} & \multirow{2}{*}{$\begin{array}{c}\text { E-Plane } \\
\text { (Borizostal-borisostal) }\end{array}$} & \multirow{2}{*}{$\begin{array}{c}\text { H.Plane } \\
\text { (rertical-rertikal) }\end{array}$} & \multicolumn{2}{|c|}{$\begin{array}{l}\text { Konbinissi E-Plane des H-Plas } \\
\text { (aonizostal - rertical) }\end{array}$} \\
\hline & & & E-Plang & HPlan? \\
\hline 1.5 & $-14.3 \AA B$ & $-15.5 \mathbb{B}$ & $-15.4 \mathrm{CB}$ & $-18.6 \mathrm{CB}$ \\
\hline 2 & $-19.5 \propto B$ & $-15.1 \AA$ & $-19.2 \sqrt{B}$ & $-19.7 \mathrm{AB}$ \\
\hline 2.5 & $-19.4 \bar{B}$ & $-17.3 \mathrm{~B}$ & $-19.1 \mathrm{BB}$ & $-19.9 \mathrm{CB}$ \\
\hline 3 & $-20.0 \bar{B}$ & $-20.0 \mathrm{CB}$ & $-20.0 \mathrm{~dB}$ & $-20.0 \mathrm{AB}$ \\
\hline 5 & $-20.0 \mathrm{CB}$ & $-20.0 \mathrm{CB}$ & $20.0 A B$ & $20.0 \mathrm{AB}$ \\
\hline Crin raterata & $-18.64 \mathrm{~dB}$ & $-17.58 \mathrm{CB}$ & $.18 .74 \mathrm{~dB}$ & $-19.64 \mathbb{B}$ \\
\hline
\end{tabular}

Nilai gain antena circular loop yang disajikan pada Tabel 9 memperlihatkan ada 4 data hasil pengukuran gain rata-rata yang menyimpang dari pernyataan teori. Pertama yaitu pada kondisi kombinasi E-Plane H-Plane, pada jarak 2 meter, nilai gain rata-rata pada -19.2 $\mathrm{dB}$ dan pada jarak 2.5 meter, nilai gain rata-rata -19.1 dB. Kedua yaitu pada kondisi E-Plane, pada jarak 2 meter, nilai gain rata-rata pada -19.5 $\mathrm{dB}$ dan pada jarak 2.5 meter, nilai gain rata-rata -19.4 dB. Berarti prosentase keakuratan hasil pengukuran gain rata-rata antena circular loop kondisi NO-LOSS dapat diperoleh dengan rumus berikut:

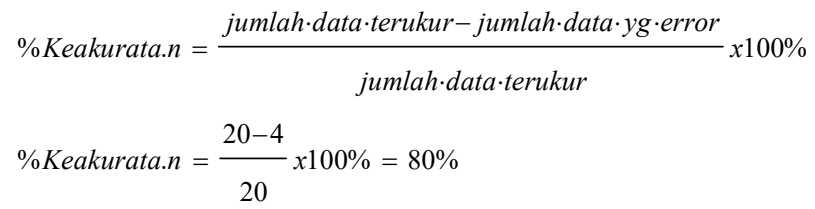

7. Pengukuran Gain dan Pola Radiasi Antena Yagi pada kondisi LOSS

Tabel 10 berikut ini menyajikan sampel pola radiasi antena yagi pada kondisi LOSS dan posisi antena yagi horizontal (E-Plane), dengan sudut azimuth $0^{0}$ sampai $330^{\circ}$.

Tabel 10. Pengukuran gain dan pola radiasi antena yagi pada kondisi Loss
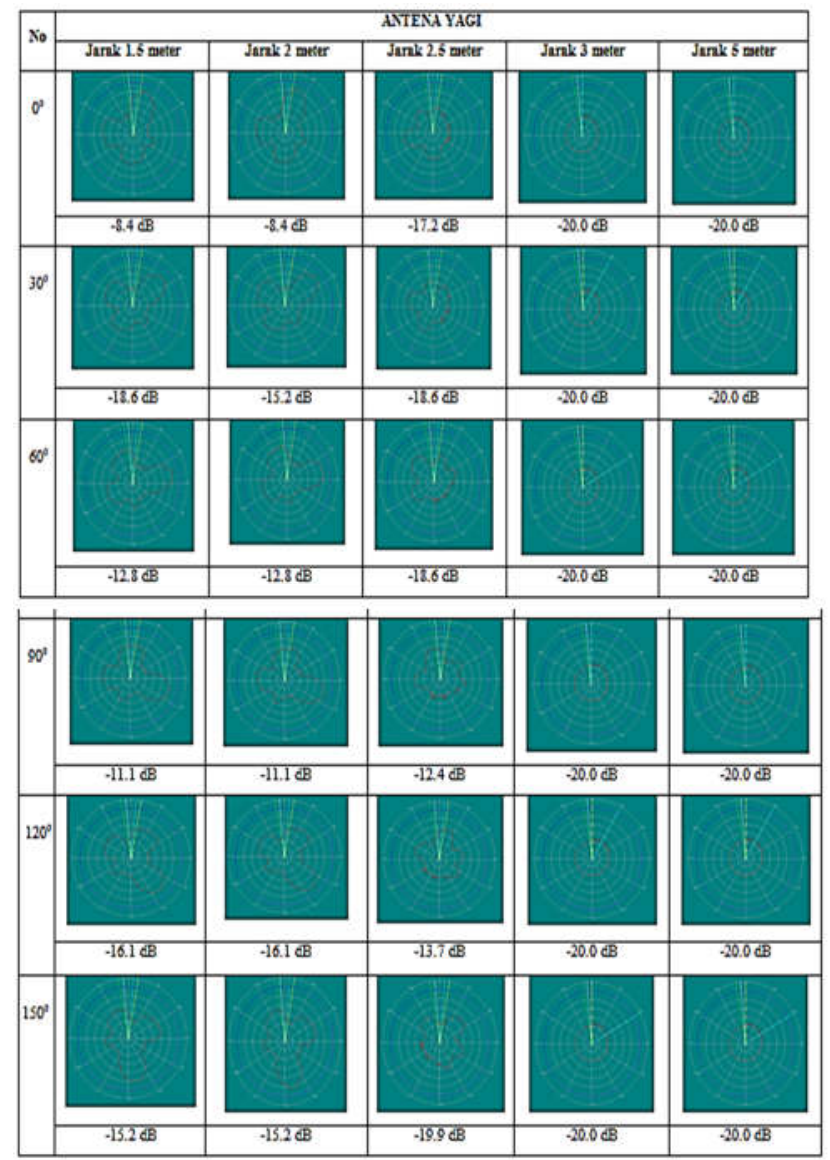

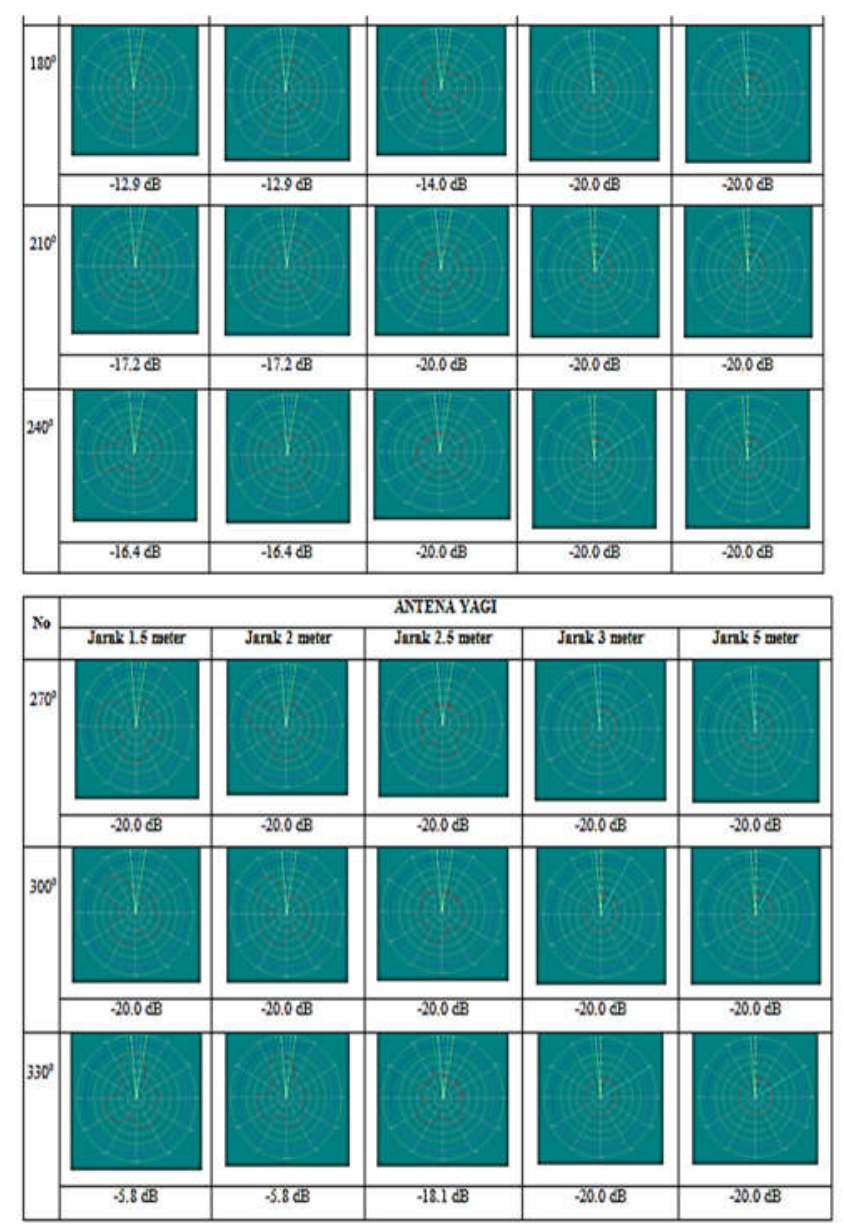

Tabel 11. Nilai gain rata-rata antena yagi pada kondisi Loss

\begin{tabular}{|c|c|c|c|c|}
\hline \multirow{2}{*}{$\begin{array}{l}\text { Jarak antenas } \\
\text { (meter) }\end{array}$} & \multirow{2}{*}{$\begin{array}{c}\text { E-Plase } \\
\text { (Bonizostal-borisontal) }\end{array}$} & \multirow{2}{*}{$\begin{array}{c}\text { H-Plase } \\
\text { (rertical-rertikal) }\end{array}$} & \multicolumn{2}{|c|}{$\begin{array}{l}\text { Kombinssi E-Plase dan H-Plave } \\
\text { (Aorizostal - rertical) }\end{array}$} \\
\hline & & & Eplan? & H.Plan? \\
\hline 1.5 & $-14.5 \mathbb{B}$ & $.13 .7 \mathrm{~B}$ & $.14 C B$ & $-14.3 \mathrm{AB}$ \\
\hline 2 & $.14 .54 \mathbb{C B}$ & $-16.5 \mathbb{B}$ & $-18.2 \mathrm{~B}$ & $-17.8 \mathrm{~dB}$ \\
\hline 2.5 & $-17.4 \mathrm{CB}$ & $-19.6 \mathrm{~dB}$ & $-18.98 \mathrm{CB}$ & $-19 \mathbb{B}$ \\
\hline 3 & $-20.0 \mathrm{~B}$ & $20.0 \mathrm{BB}$ & $20.0 \mathrm{~dB}$ & $20.0 \mathrm{CB}$ \\
\hline 5 & $20.0 \mathrm{~dB}$ & $.20 .0 \mathrm{AB}$ & $-20.0 \mathrm{CB}$ & $20.0 \mathrm{CB}$ \\
\hline Gin satrata & $-17.19 \mathrm{CB}$ & $-17.96 \mathrm{CB}$ & $-18.24 \mathrm{AB}$ & $-18.22 \mathrm{BB}$ \\
\hline
\end{tabular}

Nilai gain antena yagi kondisi Loss yang disajikan pada Tabel 11 menujukkan semakin bertambah jarak, maka nilai gain rata-rata akan semakin menurun, sehingga prosentase keakuratan hasil pengukuran gain antena yagi sangat sempurna sebesar:

$$
\begin{aligned}
& \% \text { Keakurata. } n=\frac{j u m l a h \cdot d a t a \cdot t e r u k u r-j u m l a h \cdot d a t a \cdot y g \cdot \text { error }}{j u m l a h \cdot d a t a \cdot t e r u k u r} \times 100 \% \\
& \% \text { Keakurata. } n=\frac{20-0}{20} \times 100 \%=100 \%
\end{aligned}
$$

8. Pengukuran Gain dan Pola radiasi Antena Yagi pada kondisi NO-LOSS

Tabel 12 berikut ini menyajikan nilai gain rata-rata antena yagi pada kondisi NO-LOSS.

Tabel 12. Nilai gain rata-rata antena yagi pada kondisi No- Loss

\begin{tabular}{|c|c|c|c|c|}
\hline \multirow{2}{*}{$\begin{array}{c}\text { Jarak antenna } \\
\text { (meter) }\end{array}$} & $\begin{array}{c}\text { E-Plane } \\
\text { (horizontal-horisontal) }\end{array}$ & \multirow{2}{*}{$\begin{array}{c}\text { H-Plane } \\
\text { (vertical-vertikal) }\end{array}$} & \multicolumn{2}{|c|}{$\begin{array}{c}\text { Kombinasi E-Plane dan H-Plane } \\
\text { (horizontal - vertical) }\end{array}$} \\
\cline { 4 - 5 } & $-13 \mathrm{~dB}$ & $-14.1 \mathrm{~dB}$ & $-14.7 \mathrm{~dB}$ & $-14.3 \mathrm{~dB}$ \\
\hline 1.5 & $-17.1 \mathrm{~dB}$ & $-17.5 \mathrm{~dB}$ & $-18.3 \mathrm{~dB}$ & $-18.4 \mathrm{~dB}$ \\
\hline 2 & $-18.5 \mathrm{~dB}$ & $-19.9 \mathrm{~dB}$ & $-19.2 \mathrm{~dB}$ & $-18.4 \mathrm{~dB}$ \\
\hline 2.5 & $-20.0 \mathrm{~dB}$ & $-20.0 \mathrm{~dB}$ & $-20.0 \mathrm{~dB}$ & $-20.0 \mathrm{~dB}$ \\
\hline 3 & $-20.0 \mathrm{~dB}$ & $-20.0 \mathrm{~dB}$ & $-20.0 \mathrm{~dB}$ & $-20.0 \mathrm{~dB}$ \\
\hline 5 & $-17.72 \mathrm{~dB}$ & $-18.3 \mathrm{~dB}$ & $-18.44 \mathrm{~dB}$ & $-18.22 \mathrm{~dB}$ \\
\hline Gain rata-rata & & & & \\
\hline
\end{tabular}

Nilai gain antena yagi kondisi No-Loss yang disajikan pada Tabel 12 menujukkan semakin bertambah jarak, maka nilai gain ratarata akan semakin menurun, sehingga prosentase keakuratan hasil pengukuran gain antena yagi sangat sempurna sebesar:

$\%$ Keakurata.n $=\frac{j \text { jumlah } \cdot \text { data } \cdot \text { terukur }-j u m l a h \cdot d a t a \cdot y g \cdot \text { error }}{j u m l a h \cdot d a t a \cdot t e r u k u r} \times 100 \%$
$\%$ Keakurata.n $=\frac{20-0}{20} \times 100 \%=100 \%$

Secara keseluruhan, hasil perhitungan gain rata-rata untuk 4 jenis antena penerima (antena dipole, antena monopole, antena circular loop dan antena yagi) menunjukkan bahwa antena yagi yang memiliki karakteristik yang paling bagus karena nilai gain dan pola radiasinya sangat ideal dan sempurna secara teoritis. Untuk lebih jelasnya, prosentase hasil pengukuran gain rata-rata 4 jenis antena penerima pada kondisi LOSS dan NO-LOSS dengan 5 variasi jarak, disajikan pada Tabel 13 berikut ini:

Tabel 13. Prosentase keakuratan hasil perhitungan nilai gain rata-rata untuk 4 jenis antena penerima

\begin{tabular}{|c|c|c|c|c|}
\hline Kondisi & $\begin{array}{c}\text { Antena } \\
\text { Dipole }\end{array}$ & $\begin{array}{c}\text { Antena } \\
\text { Monopole }\end{array}$ & $\begin{array}{c}\text { Antena Circular } \\
\text { Loop }\end{array}$ & Antena Yagi \\
\hline LOSS & $100 \%$ & $90 \%$ & $80 \%$ & $100 \%$ \\
\hline NO-LOSS & $90 \%$ & $80 \%$ & $80 \%$ & $100 \%$ \\
\hline
\end{tabular}

Berdasarkan Tabel 13, prosentase keakuratan antena yagi sangat sempurna yaitu $100 \%$, baik saat kondisi LOSS maupun NOLOSS. Maka dapat disimpulkan bahwa antena yagi sangat cocok digunakan secara umum, baik sebagai antena pemancar maupun sebagai antena 
penerima, karena nilai gain dan pola radiasinya sangat ideal baik dan telah dibuktikan dengan 5 variasi jarak, 3 posisi antena dengan 12 derajat kemiringan dan 2 kondisi antena (LOSS dan NOLOSS).

\section{KESIMPULAN}

Berdasarkan hasil analisa pada Bab sebelumnya, maka dapat ditarik kesimpulan sebagai berikut:

1. Pola radiasi antena dipengaruhi oleh posisi kemiringan antena

2. Gain antena dipengaruhi oleh jarak antena pemancar dan penerima. Semakin jauh jarak maka gain akan mengalami penurunan

3. Hasil pengujian kualitas antena menunjukkan bahwa diantara 4 jenis antena (dipole, monopole, circular loop dan yagi), terbukti bahwa antena yagi memiliki tingkat akurasi pengujian yang sangat sempurna sebesar $100 \%$.

4. Antena yagi terbukti memiliki nilai gain dan pola radiasi yang sangat ideal, sehingga sangat cocok diimplementasikan sebagai antena pemancar dan antena penerima.

\section{DAFTAR PUSTAKA}

[1] Lubis, A. Z. (2014). Pengaruh posisi antena terhadap sinyal gelombang antena yagi aluminium. Jurnal Dinamis, Vol.II Nomor 14.

[2] Pratama, B. (2013). Perancangan dan implementasi antena yagi $2.4 \mathrm{GHz}$. Jurnal Elkomika.

[3] Abdullah, D. (2013). Sistem Antena. Available : http://dahlan.web.id.

[4] Rokhman, D. N. (2016). Implementasi antena yagi 5 elemen sebagai penerima siaran televisi di Bandung kota. Jurnal Elektro Telekomunikasi Terapan.

[5] Krous, J. D. (1988). Antenas. McGraw-Hill Book Company.

[6] Nasrul (2003). Pembuatan Antena Triband untuk Kendaraan Bergerak. Jurnal R\& B, Volume 3 Nomor 2.
[7] Hamzah (2016). Jenis Antena. Available: http://widuribarru.blogspot.co.id/p/jenisantena.html.

[8] YD2TFB (2011). Antena Dipole dan Monopole. Available: https://www.google.co.id/search?q=polarad iasi+dipole+antena\&source

[9] Abi (2015). Memahami Jenis Antena Monopole. Available: https://www.google.co.id/search?q=polarad iasi+monopole+antena\&source

[10] Satrio, H. (2014). Perancangan Antena Dual Circular loop sebagai penerima siaran televise digital pada rentang frekuensi UHF. Available: https://www.google.co.id/search?q=pola $+\mathrm{r}$ adiasi+ideal+antena+circular+loop \&tbm 